\title{
HUBUNGAN KEINGINAN KONSUMEN TERHADAP KULINER DI WILAYAH PARIWISATA NUSA DUA, KUTA SELATAN, BADUNG
}

\author{
SUKADA, I K., I N. KAYANA, DAN I G. SUARTA \\ Fakultas Peternakan Universitas Udayana \\ e-mail:sukada@unud.ac.id
}

\begin{abstract}
ABSTRAK
Penelitian bertujuan untuk mencari peringkat yang terbaik dari kuliner di wilayah pariwisata Nusa Dua, Kuta Selatan Badung yang menggunakan bahan dasar daging broiler dan daging sapi. Tidak semua wisatawan menyukai produk kuliner tradisional seperti babi guling ataupun ayam betutu. Penelitian ini menggunakan rancangan non parametrik yang dianalisis dengan Kruskal-Wallis. Variabel yang diukur dalam penelitian ini menggunakan sekala edonik melalui beberapa fanalis antara lain: warna, tekstur, rasa, dan bau. Yang diolah dengan SPSS (Statistic Product System Solution). Hasil penelitian bahwa rasa yang paling disukai adalah pada kuliner kebab dan selanjutnya spaghetti dan hamburger yang dilihat dari nilai rank pada analisis (yang terkecil yang paling disukai) yaitu berturut-turut 9,30; 16,80; 20,40. Perbedaan ini sangat signifikan $(\mathrm{P}<0.01)$ dengan $\mathrm{R}=9,598$ yang menyatakan bahwa hubungan antar variabel sangat erat. Warna yang paling disukai adalah pada kuliner kebab dan selanjutnya spaghetti dan hamburger yang dilihat dari nilai rank pada analisis (yang terkecil yang paling disukai) yaitu berturut-turut 9,75; 16,50; 20,35 Perbedaan ini signifikan $(\mathrm{P}<0.05)$ dengan $\mathrm{R}=8,856$ yang menyatakan bahwa hubungan antar variabel sangat erat. Diperoleh bau yang paling disukai adalah pada kuliner hamburger dan selanjutnya kebab dan spaghetti yang dilihat dari nilai rank pada analisis (yang terkecil yang paling disukai) yaitu berturut-turut 9,50; 17,30; 19,70. Perbedaan ini signifikan $(\mathrm{P}<0.05)$ dengan $\mathrm{R}=8,485$ yang menyatakan bahwa hubungan antar variabel sangat erat.
\end{abstract}

Kata kunci: kebab, hamburger, spaghetti, daging broiler

\section{RELATIONSHIP OF CONSUMER DESIRES TO CULINARY IN THE TOURISM AREA OF NUSA DUA, KUTA SELATAN, BADUNG}

\begin{abstract}
This experiment aims for the highest possible rank from culinnary in Nusa Dua tourism area, South Kuta, Badung, in which, mostly based on broiler chicken and beef. In contrary, not all tourist likes the traditional culinary product such as, babi guling or ayam betutu. This experiment uses non parametric design, which analyzed using Kruskal-Wallis. Variables measured using hedonic scale from panellist, such as; color, texture, taste, and smell, then processed in SPSS (Statistic Poduct System Solution). Result as follows, for taste, kebab is on the first place, followed by spaghetti and hamburger respectively (ranks; 9.30; 16.80; 20.40, respectively). The difference is very significant $(\mathrm{P}<0.01, \mathrm{R}=9.598)$, it shows the corelation in between variables is very strong. For color, kebab also on the first place, followed by spagetthi and hamburger respectively (ranks; 9.75; 16.50; 20.35, respectively) the difference is significant $(\mathrm{P}<0.05, \mathrm{R}=8.856)$, it shows the corelation in between variables is strong. For smell, hamburger is on the first place, followed by kebab and spaghetti respectively (ranks; 9.50; 17.30; 19.70, respectively). The difference is also significant $(\mathrm{P}<0.05, \mathrm{R}=8.485)$, it shows the corelation in between variables is very strong.
\end{abstract}

Keywords: kebab, hamburger, spaghetti, broiler meat 


\section{PENDAHULUAN}

Kunjungan wisatawan mancanegara khususnya wisatawan yang ke wilayah Bali Selatan, banyak membawa pengaruh tehadap mata pencaharian penduduk. Perkembangan restoran yang dahulunya menyajikan kuliner tradisional sekarang telah banyak beradaptasi dengan kuliner kesukaan para wisatawan. Dimasa lalu penduduk lokal tidak banyak yang mengenal istilah hamburger, spaghetti dan kebab, sekarang penduduk lokal telah terbiasa menikmati rasa kuliner tersebut. Perubahan-perubahan ini mendorong para pengembang restoran menyajikan produk baru ini, baik terhadap para tamu manca negara maupun para konsumen yang berasal dari lokal daerah. Berkembangnya kuliner baru ini boleh dikatakan menyaingi makanan khas tradisional tetapi memperkaya ragam kuliner lokal yang ada. Para tamu yang sudah terbiasa membutuhkan kuliner seperti di negaranya, sering memesan kembali kuliner yang terbiasa dikonsumsi di negaranya.

Meningkatnya kunjungan wisatawan ini membawa dampak terhadap perkembangan kuliner lokal di Provinsi Bali. Tidak semua tamu manca negara terbiasa dengan produk tradisional Bali seperti babi guling dan ayam betutu. Menurut pengalaman para pengusaha restoran beberapa tamu masih berkeinginan memesan produk kuliner yang terbiasa dimakan di daerahnya. Sebaliknya para konsumen lokal sudah banyak yang mulai terbiasa menikmati produk seperti kebab, hamburger, spaghetti dan rice bowl. Berdasarkan hal ini maka untuk mendapatkan keuntungan yang lebih besar para pengusaha restoran juga membidik keinginan konsumen supaya tetap terpenuhi dan berbelanja di restorannya. Produk tradisional seperti babi guling hanya digemari oeh wisatawan dari Cina, Taiwan dan Korea, sedangkan wisatawan dari Amerika, Inggris, dan Australia masih banyak menggemari kuliner seperti kebab, humburger, spaghetti. Melihat fenomena ini para pengembang restoran dan rumah makan disamping mempromosikan produk tradisional, namun juga mengembangkan produk baru kuliner sesuai kesenangan wisatawan.

Daging ayam dan daging sapi merupakan bahan utama untuk mencampur pembuatan kuliner antarlain: kebab, spaghetti dan hamburger. Daging merupakan bahan pangan sumber protein hewani yang digemari oleh seluruh lapisan masyarakat karena rasanya yang lezat dan mengandung nilai gizi yang tinggi. Daging adalah salah satu hasil ternak yang hampir tidak dapat dipisahkan dari kehidupan manusia. Daging dapat menimbulkan kepuasan atau kenikmatan bagi yang memakannya karena kandungan gizinya yang lengkap sehingga keseimbangan gizi untuk hidup dapat terpenuhi. Soeparno (2009) mendefinisikan daging sebagai semua jaringan hewan dan semua produk hasil pengolahan jaringan tersebut yang sesuai untuk dimakan serta tidak menimbulkan gangguan kesehatan bagi yang memakannya. Kualitas fisik daging antara lain $\mathrm{pH}$, daya ikat air, susut masak dan tekstur. Kualitas fisik daging dipengaruhi oleh proses sebelum dan setelah pemotongan. Faktor sebelum pemotongan yang dapat mempengaruhi kualitas daging adalah genetik, spesies, bangsa, tipe ternak, jenis kelamin, umur, pakan termasuk bahan aditif (hormon, antibiotik, dan mineral) dan keadaan stres. Faktor setelah pemotongan yang mempengaruhi kualitas daging antara lain meliputi $\mathrm{pH}$ daging, metode penyimpanan, macam otot daging dan lokasi pada otot daging (Soeparno, 2005).

Sifat organoleptik pada daging segar, merupakan aspek yang penting diperhatikan. Hal ini berkaitan dengan pertimbangan konsumen dalam memilih daging. Biasanya konsumen akan lebih mudah memilih daging melalui penampilan secara fisik yang meliputi warna, tekstur, kecerahan, serta intensitas flavor daging segar. Menurut Soeparno (2009) penampilan daging banyak dipengaruhi oleh faktor selama pemeliharaan, penanganan sebelum pemotongan hingga penanganan setelah pemotongan. Ciri suatu otot mempunyai hubungan yang erat dengan fungsinya karena fungsinya maka jumlah jaringan ikat berbeda diantara otot. Jaringan ikat ini berhubungan dengan kealotan daging. Lebih lanjut Lawrie (2003) mengemukakan bahwa, perbedaan kadar protein daging dapat disebabkan oleh adanya perbedaan struktur dan tingkat aktifitas otot. Dengan adanya perbedaan macam otot menunjukan adanya perbedaan distribusi nitrogen sehingga tingkat aktivitas otot yang berbeda dapat menghasilkan kadar protein daging yang berbeda pula. Sifat fisik memegang peranan penting dalam proses pengolahan dikarenakan sifat fisik menentukan kualitas serta jenis olahan yang akan dibuat. Sifat fisik sangat dipengaruhi oleh faktorfaktor sebelum pemotongan dan setelah pemotongan. Faktor penting sebelum pemotongan adalah perlakuan istirahat yang dapat menentukan tingkat cekaman (stress) pada ternak. Menurut Aberle et al. (2001), ternak yang tidak diistirahatkan akan menghasilkan daging yang berwarna gelap, bertekstur keras, kering, memiliki nilai $\mathrm{pH}$ tinggi dan daya mengikat air tinggi. Faktor penting setelah pemotongan yang berpengaruh pada kualitas daging adalah pelayuan. Pelayuan daging akan berpengaruh pada keempukan, flavor dan daya mengikat air. Faktor-faktor tersebut sangat berkaitan dengan waktu postmortem atau waktu setelah pemotongan.

Proses glikolisis setelah ternak dipotong berpengaruh pada nilai $\mathrm{pH}$. Semakin lama waktu post mortem akan terjadi penurunan $\mathrm{pH}$ yang semakin rendah akibat 
proses konversi otot menjadi daging pada jarak waktu post mortem tertentu. Nilai $\mathrm{pH}$ ultimat daging yang normal berkisar antara 5,4-5,8 pada 6 jam post mortem dan warna daging akan menjadi merah cerah (Aberle et al., 2001). Menurut Lawrie (2003), pH daging dapat menurun dengan cepat hingga mencapai 5,4-5,5 selama beberapa jam setelah pemotongan. Standar $\mathrm{pH}$ daging hewan yang sehat dan cukup istirahat yang baru dipotong adalah 7-7,2 dan akan terus menurun selama 24 jam. Penurunan $\mathrm{pH}$ tersebut tidak sama untuk semua urat daging dari seekor hewan dan diantara hewan juga berbeda. Nilai $\mathrm{pH}$ post mortem akan ditentukan oleh jumlah asam laktat yang dihasilkan dari glikogen selama proses glikolisis anaerob. Nilai $\mathrm{pH}$ akan semakin rendah pada hewan yang mengalami stress sebelum pemotongan dan akan dihasilkan daging yang pucat, lembek dan berair (pale, soft, exudative = PSE). Purnomo dan Adiono (1985) menambahkan, terbentuknya asam laktat menyebabkan penurunan $\mathrm{pH}$ daging dan menyebabkan kerusakan struktur protein otot dan kerusakan tersebut tergantung pada temperatur dan rendahnya $\mathrm{pH}$. Setelah hewan dipotong, penyediaan oksigen otot terhenti, dengan demikian persediaan oksigen tidak lagi di otot dan sisa metabolisme tidak dapat dikeluarkan lagi dari otot, sehingga daging akan mengalami penurunan $\mathrm{pH}$.

Beberapa karakteristik kualitas daging yang penting dalam pengujian dan mempengaruhi daya tarik konsumen yakni $\mathrm{pH}$, daya ikat air, warna dan keempukan (Purbowati et al., 2006). Daya ikat air adalah kemampuan daging untuk mempertahankan kandungan air selama mengalami perlakuan dari luar seperti pemotongan, pemanasan, penggilingan, dan pengolahan. Besar kecilnya daya ikat air berpengaruh terhadap warna, keempukan, kekenyalan, kesan jus, dan tekstur daging (Suardana dan Swacita, 2009). Daya ikat air daging sangat dipengaruhi oleh $\mathrm{pH}$, spesies, umur dan fungsi otot serta pakan, transportasi, temperatur kelembaban, penyimpanan, jenis kelamin, kesehatan, perlakuan sebelum pemotongan dan lemak intramuskuler (Soeparno, 2005). Nilai pH merupakan salah satu kriteria dalam penentuan kualitas daging sapi. Nilai pH daging pada ternak sapi yang masih hidup sekitar 7,0-7,2 ( $\mathrm{pH}$ netral). Penurunan nilai $\mathrm{pH}$ akan terjadi setelah hewan ternak sapi disembelih (post mortem) yaitu pada saat jantung berhenti memompa darah, sehingga jaringan otot dan jaringan lainnya tidak mendapat suplai darah. Faktor yang berpengaruh terhadap $\mathrm{pH}$ daging diantaranya: stress sebelum pemotongan, hormon/obat-obatan, spesies, individu ternak dan macam otot, stimulasi listrik, aktivitas enzim, dan terjadinya glikolosi, pelunakan kolagen, sedangkan temperatur pemasakan lebih mempengaruhi kealotan miofibrilar (Dwiloka et al.,
2006). Besarnya susut masak dapat dipengaruhi oleh banyaknya kerusakan membrane seluler, banyaknya air yang keluar dari daging, umur simpan daging, degradasi protein, dan kemampuan daging mengikat air (Shanks et al., 2002). Susut masak merupakan indikator nilai nutrisi daging yang berhubungan dengan kadar air daging, yaitu banyaknya air yang terikat di dalam dan diantara otot. Daya ikat air yang rendah akan mengakibatkan nilai susut masak yang tinggi. Water Holding Capacity (WHC) sangat dipengaruhi oleh nilai $\mathrm{pH}$ daging, menurut Soeparno (2005) apabila nilai $\mathrm{pH}$ lebih tinggi atau lebih rendah dari titik isoelektrik daging $(5,0-5,1)$ maka nilai susut masak daging tersebut akan rendah. Daging sapi bali dan wagyu mempunyai nilai uji organoleptik yang berbeda karena terdapat perbedaan dari breed sapi sehingga memberikan nilai hasil tingkat kesukaan yang berbeda pula. Perbedaan breed tersebut kemungkinan dapat berpengaruh terhadap karakteristik fisik daging seperti nilai daya ikat air (DIA), tingkat keasaman (pH), dan susut masak daging. Susut masak (cooking loss) merupakan fungsi dari suhu dan lama pemasakan (Hartono et al., 2013). Lama waktu pemasakan mempengaruhi.

Daging mempunyai sifat organoleptik yang dapat berkaitan dengan lima sifat dasar yaitu rasa (taste), bau (smell), penampilan/warna (sight), kehalusan (feel) dan kekerasan. Empat rasa dasar yang diidentifikasi dari daging adalah rasa asin, asam, manis dan pahit (Abustam dan Ali, 2004). Pengujian organoleptik adalah pengujian yang didasarkan pada proses pengindraan. Penginderaan diartikan sebagai suatu proses fisio-psikologis, yaitu kesadaran atau pengenalan alat indra akan sifat-sifat benda karena adanya rangsangan yang diterima alat indra yang berasal dari benda tersebut. Penginderaan dapat juga berarti reaksi mental (sensation) jika alat indra mendapat rangsangan (stimulus). Uji organoleptik adalah suatu pengujian sifat-sifat bahan pangan yang dilakukan dengan menggunakan alat indera pengecap, pembau, penglihatan dan peraba. Uji yang dilakukan adalah uji kesukaan (uji hedonik) yang meliputi rasa, aroma, warna, tekstur dan keempukan (Soeparno, 2009).

\section{MATERI DAN METODE}

\section{Materi}

Materi penelitian menggunakan 3 jenis kuliner yaitu: kebab, spaghetti dan hamburger yang menggunakan daging ayam dan daging sapi, diperoleh dari beberapa restoran lokal di wilayah Tanjung Benoa dan Nusa Dua. Kebab merupakan kuliner yang memiliki kulit pembungkus dari tepung tertentu yang dibuat sedemikian rupa didalamnya diisi daging broiler goring yang di potong-potong dan diisi bumbu sesuai 
selera konsumen yang memesan yang dibuat oleh pegawai restoran. Hamburger merupakan kuliner yang terbuat dari roti burger yang dibelah ditengah-tengah lalu diisi potongan daging broiler goring yang dicincang tips-tipis dan diisi pada roti burger tersebut. Spaghetti merupakan kuliner dari mie spaghetti dicampur bumbu yang berisi juga daging broiler, penampilan kuliner ini sangat sederhana hanya berupa mie yang berisi bumbu dan daging cincang yang sangat enak rasanya.

\section{Lokasi dan Waktu Penelitian}

Penelitian dilaksanakan di Laboratoriam Teknologi dan Hasil Ternak Fakultas Peternakan Universitas. Penelitian dimuali tanggal 5 Januari sampai bulan 5 April 2020.

\section{Variabel}

Kualitas organoleptik daging sapi bali dinilai panalis yang telah ditentukan. Pada penelitian ini parameter organoleptik yang akan diamati yaitu warna, dan rasa serta uji yang akan dilakukan oleh 9 panelis. Panelis sebelumnya dilatih terlebih dahulu mengenal sifat organoleptik yang akan diujikan. Penilaian menggunakan uji skala kualitas organoleptik dinilai dengan sekala uji angka 1 sampai 5. Panelis yang sudah memahami kriteria skala organoleptik yang akan diuji masing-masing diberikan label penilaian. Panelis melakukan penilaian dengan memberi tanda silang pada label nilai yang dipilih yang dianggap cocok menurut panelis. Sampel daging sapi bali yang sudah siap dinilai disajikan pada masing-masing wadah sesuai perlakuan yang direncanakan dalam penelitian. Sebelum melakukan uji panelis tentang sifat organoleptik, terlebih dahulu disediakan 10 panelis dan masing-masing panelis diberikan empat jenis kuliner (kebab, spaghetti, hamburger dan rice bowl) untuk memberikan peringkat nilai mengenai, rasa, warna, bau, dan texture dan diperoleh data dari masing-masing panelis. Dengan skala hedonic yang sudah ditentukan. Variabel penelitian bersifat kualitatif sifat organoleptik dari kebab, spaghetti, dan hamburger.

\section{Rancangan Penelitian}

Rancangan penelitian yang digunakan adalah rancangan non para metrik yaitu Metode Kruskal Wallis yang diolah dengan SPSS (Statistic Product System Solution).

\section{Analisa Data}

Analisa data secara kualitatif menggunakan skala hedonic diolah dengan Metode Kruskal Wallis melalui SPSS.

\section{HASIL DAN PEMBAHASAN}

\section{Rasa}

Rasa menempati peringkat pertama terhadap penerimaan konsumen. Rasa suatu bahan pangan dipengaruhi oleh beberapa faktor yaitu senyawa kimia, temperatur, konsistensi, dan interaksi dengan komponen rasa yang lain serta jenis dan lama pemasakan. Diperoleh rasa yang paling disukai adalah pada kuliner kebab dan selanjutnya spaghetti dan hamburger yang dilihat dari nilai rank pada analisis (yang terkecil yang paling disukai) yaitu berturut-turut 9,30; 1, 6,80; 20,40. Perbedaan ini sangat signifikan $(\mathrm{P}<\mathrm{O}, \mathrm{O} 1)$ dengan $\mathrm{R}=9,598$ yang menyatakan bahwa hubungan antar variabel sangat erat.

Data hasil pengamatan dari 10 analis yang sudah berpangalaman mengenai rasa

\begin{tabular}{cccc}
\hline No. & Kebab & Hamburger & Spaghetti \\
\hline 1 & 1 & 2 & 2 \\
2 & 2 & 3 & 2 \\
3 & 3 & 2 & 2 \\
4 & 1 & 3 & 3 \\
5 & 2 & 3 & 3 \\
6 & 3 & 3 & 2 \\
7 & 1 & 3 & 2 \\
8 & 1 & 2 & 3 \\
9 & 1 & 3 & 3 \\
10 & 1 & 3 & 2 \\
\hline
\end{tabular}

Data hasil pengamatan dari 10 analis yang sudah berpangalaman mengenai rasa

\begin{tabular}{lcc}
\hline Rasa & N & Mean Rank \\
\hline Rasa Kebab & 10 & 9.30 \\
Rasa Hamburger & 10 & 20.40 \\
Rasa Spaghetti & 10 & 16.80 \\
Total & 30 & \\
\hline
\end{tabular}

\section{Test Statistic (ab)}

\begin{tabular}{cc}
\hline & Rasa \\
\hline Chy Square & 9,598 \\
Df & 2 \\
Asymp.Sig & 0.008 \\
\hline
\end{tabular}

\section{Bau}

Aroma merupakan salah satu parameter penilaian organoleptik terhadap suatu produk. Salah satu yang dapat mempengaruhi aroma daging masak yaitu temperatur pemasakan (Soeparno, 2009). Pada umumnya bau yang diterima oleh hidung dan otak lebih banyak merupakan berbagai ramuan atau campuran empat bahan utama yaitu harum, asam, tengik, dan hangus (Winarno, 2004). Diperoleh bau yang paling disukai adalah pada kuliner hamburger dan selanjutnya kebab dan spaghetti yang dilihat dari nilai 
rank pada analisis (yang terkecil yang paling disukai) yaitu berturut-turut 9,50;17,30; 19,70. Perbedaan ini signifikan $(\mathrm{P}<0,05)$ dengan $\mathrm{R}=8,485$ yang menyatakan bahwa hubungan antar variabel sangat erat.

Data hasil pengamatan dari 10 analis yang sudah berpangalaman mengenai bau

\begin{tabular}{cccc}
\hline No. & Kebab & Hamburger & Spaghetti \\
\hline 1 & 2 & 1 & 2 \\
2 & 2 & 1 & 2 \\
3 & 2 & 2 & 3 \\
4 & 2 & 3 & 2 \\
5 & 3 & 1 & 3 \\
6 & 3 & 2 & 3 \\
7 & 2 & 3 & 3 \\
8 & 2 & 1 & 3 \\
9 & 3 & 1 & 2 \\
10 & 3 & 1 & 3 \\
\hline
\end{tabular}

\begin{tabular}{lcc}
\hline Bau & N & Mean Rank \\
\hline Kebab & 10 & 17.30 \\
Hamburger & 10 & 9.50 \\
Spaghetti & 10 & 19.70 \\
Total & 30 & \\
\hline
\end{tabular}

\section{Test Statistic (ab).}

\begin{tabular}{lc}
\hline & Bau \\
Chy Square & 8.485 \\
Df & 2 \\
Asymp.Sig & 0.014 \\
\hline
\end{tabular}
a. Kruskal Wallis Test
b. Grouping variabel media

\section{Warna}

Warna juga dapat digunakan sebagai indikator kesegaran atau kematangan. Baik tidaknya cara pencampuran atau cara pengolahan dapat ditandai dengan adanya 11 warna yang seragam dan merata (Winarno, 2004). Warna pada daging yang dimasak umumnya berwarna abu-abu perubahan warna tersebut disebabkan oleh denaturasi globin dan reaksi maillard. Menurut Lawrie (2003) selain disebabkan oleh pigmen, perubahan warna pada daging yang dimasak juga akibat hasil denaturasi globin dan dipengaruhi oleh karamelisasi karbohidrat serta reaksi maillard antara gula-gula pereduksi dan asam amino. Mioglobin merupakan pigmen utama daging dan konsentrasinya akan mempengaruhi intensitas warna merah daging. Perbedaan kadar mioglobin menyebabkan perbedaan intensitas warna daging. Faktor penentu warna daging dipengaruhi oleh pakan, spesies, bangsa, umur, jenis kelamin, stres (tingkat aktifitas dan tipe otot). Diperoleh warna yang paling disukai adalah pada kuliner kebab dan selanjutnya spaghetti dan hamburger yang dilihat dari nilai rank pada analisis (yang terkecil yang paling disukai) yaitu berturut-turut 9,$75 ; 16,50 ; 20,35$ Perbedaan ini significant $(\mathrm{p}<0.51)$ dengan $\mathrm{R}=8,856$ yang menyatakan bahwa hubungan antar variabel sangat erat.

Data hasil pengamatan dari 10 analis yang sudah berpangalaman mengenai warna

\begin{tabular}{cccc}
\hline No. & Kebab & Hamburger & Spaghetti \\
\hline 1 & 2 & 2 & 2 \\
2 & 2 & 3 & 2 \\
3 & 2 & 2 & 3 \\
4 & 3 & 3 & 1 \\
5 & 3 & 3 & 2 \\
6 & 2 & 3 & 3 \\
7 & 2 & 3 & 1 \\
8 & 3 & 2 & 1 \\
9 & 3 & 3 & 1 \\
10 & 2 & 3 & 1 \\
\hline
\end{tabular}

Data hasil pengamatan dari 10 analis yang sudah berpangalaman mengenai warna

\begin{tabular}{lcc}
\hline Warna & N & Mean Rank \\
\hline Kebab & 10 & 9,75 \\
Hamburger & 10 & 20,35 \\
Spaghetti & 10 & 16,50 \\
Total & 30 & \\
\hline
\end{tabular}

Test Statistic (ab).

\begin{tabular}{lc}
\hline & Warna \\
\hline Chy Square & 8,586 \\
Df & 2 \\
Asymp.Sig & 0.014 \\
\hline
\end{tabular}
a. CKruskal Wallis Test
b. Grouping variabel media

\section{SIMPULAN}

Berdasarkan hasil penelitian diperoleh hasil bahwa dari cita rasa yang paling disukai berdasarkan panelis dan pengolahan data diperoleh berturut-turut rasa warna dan bau yang paling tinggi adalah: kebab, hamburger dan spaghetti.

\section{UCAPAN TERIMAKASIH}

Pada kesempatan ini penulis mengucapkan terimakasih kepada Bapak Dr. Ir. Komang Tirta Ariyana, MSi, selaku Dekan Fakultas Peternaka Universitas Udayana, yang telah memberikan fasilitas dan tempat penelitian kepada penulis 


\section{DAFTAR PUSTAKA}

Aberle, H. B., J. C. Forrest, E. D. Hendrick., M. D. Judge dan R. A. Merkel. 2001. Principle of Meat Science. 4th edition. Kenda/ Hunt Publishing. Iowa.

Adiono, Purnomo Hari. 1985. Ilmu Pangan.Jakarta : Universitas Indonesia (UIPress).

Dwiloka B, Rianto E., Ekawati R. 2006. Perbandingan kualitas "Blade" sapi lokal dan sapi impor yang diolah dengan metode "Pan Frying". Universitas Diponegoro. JSains Teknologi Ternak 2(1): 8-22

Hartono E, Iriyanti N., Santosa R., Sugeng S. 2013. penggunaan pakan fungsional terhadap daya ikat air, susut masak, dan keempukan daging ayam broiler. Purwokerto. J Ilmiah Peternakan 1(1):10-19

Lawrie, R. A. 2003. Ilmu Daging. Edisi 5 Penerjemah Aminuddin Parakkasi. Penerbit Universitas Indonesia, Jakarta.

Masudana, I W. 1990. Pengembangan sapi Bali di Bali dalam sepuluh tahun terakhir (1980-1990).
Proceeding Seminar Nasional sapi Bali. Denpasar, 20-22 September 1990.Fakultas Peternakan Universitas Udayana Denpasar.: A11-A30

Purbowati E, Sutrisno C. I., Baliarti E., Budhi S. P. S., Lestariana W. 2006. Karakteristik fisik otot Longissimus dorsi dan Biceps femoris domba lokal jantan yang dipelihara di pedesaan pada bobot potong yang berbeda. J Protein 33 (2): 147-153.

Shanks, B. C., Wolf D. M., Maddock R. J. 2002. Technical note: The effect of freezing on warner bratzler shear force values of beef longissimuss steak across several postmortem aging periods. J Anim Sci. 80: 2122- 2125.

Suardana, I W. dan I. B. N. Swacita. 2009. Higiene Makanan. Udayana University Press, Denpasar, Bali

Suwiti, N. K., P. Suastika, I. B. N. Swacita, W. Piraksa. 2013. Tingkat Kesukaan Wisatawan Asing di Bali Terhadap Daging Sapi Bali dan Wagyu. Prosiding Seminar Nasional Sapi Bali. Hal 42. 